\title{
Article
}

\section{Designing Effective Training Programs for Discipline-Specific Peer Writing Tutors}

Shelley Appleby-Ostroff

University of Ottawa

\begin{abstract}
This article demonstrates how the training of peer writing tutors in a disciplinary setting can be informed by writing centre scholarship and framed by the "Statement on Writing Centres and Staffing" (Graves, 2016). More particularly, the article offers a set of theory-supported criteria for designing effective training programs for peer tutors working in discipline-specific writing centres. It then describes a writing tutor-training program developed for an Eastern Ontario law school that incorporates many of the training criteria. The criteria are derived from theories about writing centre pedagogy, the writing process, and effective training for peer writing tutors. The criteria are framed by three of the statement's "Best Instructional Practices for Writing Centres": (1) peer tutors need to be educated and mentored; (2) writing support is best attended to in disciplinary contexts; and (3) writing professionals use and apply research from writing studies.
\end{abstract}

\section{Introduction}

Most university writing centres are open to the entire student population. In these general writing centres, tutors work with a variety of writers and types of writing. During one shift at a campus-wide writing centre, a tutor might conference with an undergraduate political science student about how to start a research essay, a legal studies student about structuring a case brief, and a graduate student about developing an argument in a theoretically complex dissertation. To be of greatest benefit to all students, these writing centre tutors must be knowledgeable about a range of genres and disciplinary conventions.

Other university writing centres are restricted to students studying specific disciplines. For example, the University of Toronto houses separate specialized writing centres for French, 
Volume 27, 2017

http://journals.sfu.ca/cjsdw

philosophy, architecture, engineering, health sciences, and education students. Tutors working in these discipline-specific writing centres must have specialized content knowledge and at least a Master's degree in a relevant discipline (University of Toronto, 2017).

While talking about writing is "the lifeblood" (North, 1984, p. 444) of both general and disciplinespecific writing centres, writing centre tutors do much more than engage their peers in casual conversations about writing. Common conferencing activities include: (a) identifying a writer's specific writing strengths and challenges; (b) offering a reader's response to a writer's work; (c) discussing different revision strategies, rhetorical choices, and approaches; and (d) advising writers on issues of clarity, style, and argument structure. Knowing when and how to carry out each of these activities requires effective training and thoughtful preparation.

But what does effective training for writing tutors working in university writing centres involve? It depends, according to writing centre scholarship. Just as each writing centre serves a different population, exists for a different purpose, aims to meet different objectives, supports different academic programs, has access to different resources, and offers different services, each writing centre has different training needs for its tutors. The training that may be effective in preparing tutors to work in a university-wide writing centre serving all students, for instance, will not necessarily be sufficient for tutors working in a small discipline-specific writing centre. And tutors providing written commentary on students' writing, or writing support in a classroom, may require more specialized training.

Despite these different tutor-training needs, much of the writing centre literature suggests that most tutor training shares common features (e.g., Bannister-Wills, 1984; Bickford, 2006). This article strives to link writing centre scholarship and practice by offering a set of theory-supported criteria for designing effective training for peer tutors working in discipline-specific writing centres, and then describing the training program developed for the University of Ottawa's law school that incorporates many of the training criteria. The criteria are derived from theories about writing centre pedagogy, the writing process, and effective training for peer writing tutors. The criteria are also framed by three of the "Best Instructional Practices for Writing Centres" from the "Statement on Writing Centres and Staffing" (Graves, 2016), endorsed by the Canadian Association for the Study of Discourse and Writing on May 30, 2016: (1) peer tutors need to be educated and mentored; (2) writing support is best attended to in disciplinary contexts; and (3) writing professionals use and apply research from writing studies.

The article comprises two main parts. In Part I, I discuss the three most pertinent areas of the 
Volume 27, 2017

http://journals.sfu.ca/cjsdw

literature related to writing centre pedagogy, the writing process, and effective training for peer writing tutors that I relied on in developing the training criteria. In Part II, I describe the tutor training program at the University of Ottawa's law school in relation to the tutor training criteria.

\section{Part I. Theoretical Underpinnings of the Tutor Training Criteria}

This part is divided into three sections, each corresponding to one of the areas of the writing centre literature that informed my thinking as I developed the tutor training criteria. For ease of reference for those who may be interested in drawing on this information in creating their own programs, I present the criteria as a table in the appendix. In the first section, I explain the theoretical foundations of the role of writing tutors. In the second section, I outline the factors contributing to the success of peer writing conferences. In the third section, I describe the common approaches to, and features of, effective tutor training.

\section{The Tutoring Role}

The literature concerning the theories underlying the tutoring role provided essential background information to develop the tutor training criteria. I also derived certain components of the criteria related to the writing and tutoring processes from this area of the literature.

The Three Main Foundational Theories. Early writing centres (or "labs") were built on a writing theory popular in the first half of the 20th century known as the current-traditional paradigm (Young, 1978). Underlying the current-traditional paradigm is the positivist view that knowledge is external and objective, and that writers should aim to convey that knowledge precisely and correctly (Hobson, 1992). Because of this product-centred perspective on writing, tutors in the first writing centres engaged in a lecturer/passive learner remedial approach to tutoring, focusing on creating mechanically correct documents.

As the writing process movement took hold, most North American university writing centres moved away from the traditionalist emphasis on error avoidance and toward expressivism, or neoRomanticism (North, 1984). According to expressivist composition theorists, knowledge is internal and subjective, and writing is an inner-directed, goal-driven, recursive process of planning, translating, and reviewing performed by an individual (e.g., Flower \& Hayes, 1981). Consistent with this view of writing as a solitary cognitive activity, writing centres started to focus less on written products and more on individual writers and their writing process, as well as on the connection 
Volume 27, 2017

http://journals.sfu.ca/cjsdw

between thinking and writing. Writing tutors were encouraged to use open-ended, or Socratic, questioning and other techniques to draw knowledge from writers and assist them "in learning how to tap into [their] latent repository" (Hobson, 1992, p. 67). Tutors were also urged to avoid proofreading and editing. Conferences were held at various stages in the writing process and writing centres aspired to "produce better writers, not better writing" (North, 1984, p. 438).

Social constructionists questioned the expressivist view that knowledge resides solely within individuals. From the social constructionist perspective, knowledge arises from the interaction between individuals and society (Hobson, 1992). Writing from the social constructionist perspective "is social in its essence" (Freedman \& Medway, 1994, p. 5) - a social process (Ede, 1989), rather than an individual activity, that "can only be understood in its community context" (Bizzell, 1982, p. 398). Since each "discourse community", or social group constituted through writing (Swales, 1990), has its own unwritten rules, conventions and practices, social constructionists believe that writing is shaped by the social and rhetorical contexts within which it occurs.

These social constructionist ideas laid the foundation for a collaborative learning approach to writing instruction, especially in writing centres. Unlike in the traditional teacher-dominated classroom, collaboration is key in modern writing centres. During most writing centre conferences, student writers and tutors learn from and with each other - "work[ing] together to create shared knowledge and a shared text" (Henning, 2001, p. 1). Tutors frequently use process-oriented strategies, such as asking writers open-ended, nondirective guiding questions and actively listening to their responses; addressing global writing concerns before sentence-level concerns; and intervening as little as possible. Through the generative power of this type of dialogue, writers maintain ownership of, and are encouraged to discover ways to improve, their own writing (Bruffee, 1984; Harris, 1986).

Implications for Discipline-Specific Tutor Training. Depending on the context in which they practice, discipline-specific writing tutors may be required to draw from any one, or a combination, of the three main theories outlined above. In the law school context, for example, peer writing tutors may need to rely on the current-traditional paradigm to explain the formal conventions of a legal document, expressivism to provide insight into a writer's composing process, or social constructionism to help one of their peers enter the legal discourse community. Understanding the theoretical foundations for effective writing-tutoring fosters a balanced and flexible approach to tutoring. Training for writing tutors in disciplinary settings should, therefore, provide tutors with the tools to develop that understanding. 
Volume 27, 2017

http://journals.sfu.ca/cjsdw

For example, tutors should learn about the writing process and be able to apply that knowledge in their practices. This means that writing tutors, through their training, should: (a) understand writing as a process of investigation and discovery; (b) become aware of their own writing processes; and (c) gain insight into other writers' writing processes. Tutors should also be taught how to use nondirective tutoring strategies such as: building rapport, actively listening, asking open-ended questions, talking about the writing process, and addressing global writing concerns before sentencelevel concerns.

In the next section, I discuss the relevant literature related to conducting effective writing conferences that I relied on in including various tutoring strategies in the tutor training criteria, and in developing the training components related to the tutor selection process and disciplinary knowledge.

\section{Factors Contributing to the Success of Peer Writing Conferences}

While collaborative learning, social constructionist, and expressivist theories presume that a successful writing conference is one in which a tutor uses nondirective or "minimalist" (Brooks, 1991) tutoring strategies - with the writer talking more than the tutor, and where the tutor and writer work together to create shared knowledge - these presumptions are not fully supported by empirical research. In one study, Blau, Hall, and Strauss (1998) found that using too many minimalist tutoring strategies can result in unproductive and unfocused conferences. Other studies suggest that more directive tutoring strategies can be effective in conferences with inexperienced and multilingual writers (e.g., Blau \& Hall, 2002), and in discipline-specific conferences (Dinitz \& Harrington, 2014). These qualifications to the findings of mainstream research also proved relevant in developing criteria for designing training for peer writing tutors working in disciplinary settings.

Three "Key Characteristics” of Successful Writing Conferences. From her analysis of empirical writing centre research, Henning (2001) identified the following three "key characteristics" of successful writing conferences: (1) the tutor and writer negotiate an agenda "that meets the writer's expectations" (p. 3); (2) the tutor helps the writer acquire and apply the knowledge he or she needs to move forward with his or her writing; and (3) the tutor establishes rapport with the writer. To achieve these characteristics, Henning argues, tutors are often required to use directive tutoring methods. For example, to negotiate an agenda successfully, tutors might need to dominate a conference from time to time. At other times, explicit instruction may be a more effective way for tutors to help certain writers acquire and apply the knowledge they need than trying to elicit that 
Volume 27, 2017

http://journals.sfu.ca/cjsdw

information from writers through open-ended, probing questions. And rigidly adhering to a nondirective question-and-answer tutoring style throughout their conferences may prevent tutors from both building and maintaining rapport with writers.

Henning (2001) points out that her list of key characteristics "echoes" (p. 4) the views Muriel Harris expressed in 1995 (Harris, 1995) and, therefore, is neither new nor surprising. What is surprising to Henning is that, because tutors are often required to use both directive and nondirective methods in "reaching these characteristics", the "ideal" writing conference "may not always be nondirective, expressionist and collaborative" (p. 11).

A better indicator of writing conference success, then, may be a tutor's flexibility about different tutoring models and approaches (e.g., Blau et al., 1998). Blau et al. (1998) argue that this "informed flexibility" (p. 38) is "the most useful conferencing model" for the following reasons:

...it makes sense to use a non-directive approach for dealing with ideas, structure and voice, to help students figure out for themselves what they are trying to say and how best to say it. But it also makes sense to instruct when necessary, particularly on formal rules of grammar and mechanics. We saw too many examples of tutors dancing around a direct question, when they clearly knew the answer, wasting the already too-short time they had to spend with their clients. (p. 38)

Two essential components of effective tutor training can be derived from this reasoning: (1) helping tutors develop a repertoire of effective directive and nondirective tutoring strategies; and (2) teaching tutors how to adapt these strategies in a balanced and flexible way to address their peers' writing concerns.

Writing Tutors' Personal Attributes. In addition to "informed flexibility" or "adaptability" (Sloan, 2007), writing centre scholars imply that certain personal attributes affect tutors' ability to conduct successful writing conferences. Freedman (1984), for example, identifies tutors' "warmth, ease, tact, [and] firmness" (p. 96) as "undefinable personality characteristics" (p.96) that contribute to writing conference success. Other important tutor attributes for Freedman are "curiosity, openness, flexibility, [and] tolerance" (p. 96) - "intellectual qualities that will make the tutors receptive to new learning" (p. 96). The following additional tutor attributes are frequently discussed in the writing centre literature: true concern for helping writers (e.g., North, 1982); good listening skills (e.g., Arfken, 1982); patience (e.g., Olson, 1984); ability to explain complex ideas and 
Volume 27, 2017

http://journals.sfu.ca/cjsdw

information accurately and clearly (e.g., Olson, 1984; Arfken, 1982); and adeptness at establishing and maintaining rapport (e.g., North, 1982).

More recently, researchers have identified three other tutor attributes that contribute to success in writing conferences. The first two additional attributes flow from Stonerock's (2005) examination of the relationship between tutor training and tutor practice: (1) tutors' willingness to reflect on, and learn from, their failures; and (2) tutors' ability to transfer what they learn in tutor training to writing conference practice. The third additional attribute comes from Sloan's (2007) study of the relationship between writing centre theory and practice. In his study, Sloan found that "a vital component of effective tutoring" is an "intangible 'social keenness"' that is neither explicitly taught nor learned in tutor training. Sloan defines "social keenness" as "the ability to 'read' a writer and respond in a nurturing, productive way" (p. 104).

Whether tutors possess any of these three attributes would likely not be evident until tutors have had some tutoring practice. Conducting interviews with prospective tutors and checking their references, however, would likely reveal most of the other personal attributes listed above.

Tutors' Use of Specific Tutoring Strategies. Another factor that the writing centre literature identifies as contributing to writing conference success is the way tutors use specific strategies to respond to writers' work. I relied on this area of the writing centre scholarship to build the list of effective tutoring strategies included in the tutor training criteria.

One popular tutor-training manual (McAndrew \& Reigstad, 2001) presents a variety of tutoring models and strategies organized around "higher order concerns (HOCs), lower order concerns (LOCs), and the piece as a whole" (p. 42). HOCs for McAndrew and Reigstad are "central" or global writing issues that weaken a paper as a whole "such as matters of thesis and focus, development, structure and organization, and voice" (p. 42). LOCs are sentence-level concerns or "matters related to surface appearance, correctness, and standard rules of written English" (p. 56)

A particularly effective tutoring strategy, according to McAndrew and Reigstad, as well as authors of other popular tutor-training manuals (e.g., Gillespie \& Learner, 2008), is to address global writing concerns before sentence-level concerns. Organizing conferences around global concerns helps writers recognize the all-important distinction between writing errors that interfere with communication, or with developing a clear line of argument in a paper, and those that do not. Another oft-cited reason for focusing conferences on global concerns is that writers can usually identify and correct their own sentence-level errors when they get some distance from their work and begin to see their writing from their readers' perspective. 
Volume 27, 2017

http://journals.sfu.ca/cjsdw

Other frequently used strategies discussed in the writing centre literature include "interpersonal (aimed at relationship building) and motivational (ways to engage writers)" (Fitzgerald \& Ianetta, 2016, p. 56) strategies such as: negotiating conference agendas that meet writers' expectations; asking open-ended questions and actively listening to the answers; giving authentic and specific praise; talking about the writing process; listening to writers read their texts aloud; teaching selfediting techniques; addressing a limited number of issues; focusing on patterns of error when addressing sentence-level concerns; providing a reader's perspective on a writer's work; and being flexible and reflective.

The literature suggests that certain of these strategies may not be effective with multilingual writers, however. For example, lack of fluency in English may make reading aloud particularly uncomfortable or difficult; questioning of any kind can be fruitless when a writer has a limited understanding of syntactical or grammatical conventions; certain multilingual writers may mistake problems of idea development or logic for grammar issues; and some multilingual writers may not be able to distinguish between sentence-level and global concerns (Blau \& Hall, 2012). In such cases, one or more of the following four tutoring strategies may be effective: (1) offering to read various sections of the writer's document aloud; (2) being directive and to the point when explaining sentence-level concerns related to mechanics, idioms, or grammar; (3) going through part of the writer's document line by line and discussing as many problems with clarity and sentence construction as possible; and (4) interweaving discussions of both global and sentence-level concerns, focusing on sentence-level errors that affect the document's overall clarity and meaning.

Most writing centre scholars agree that knowing when and how to use each tutoring strategy is essential to effective tutoring. For example, in her comprehensive empirical study about the ways tutors use, and writers perceive, different tutoring strategies, Brown (2008) found that tutors' broad use of three main strategies to address both global and sentence-level concerns affects writers' satisfaction with their conferences. The three main strategies Brown identified are: "Open-Ended Questioning", "Reader Response", and "Suggestion". According to Brown, tutors typically use OpenEnded Questioning when they want to elicit more detailed information from writers, employ Reader Response when they wish to demonstrate how they understand writers' texts and ideas about their texts, and apply Suggestion when they want writers to revise their writing in specific ways after their conferences. Brown also found that tutors use the Suggestion strategy in two different ways: (1) to identify and correct an error; and (2) to identify an error without correcting it, implying that the writer should correct the error (p. 40). 
Volume 27, 2017

http://journals.sfu.ca/cjsdw

While the writers in Brown's study perceived Open-Ended Questioning as effective in helping them focus on global concerns, these same questions seemed "more leading" (p. 109) -and less effective -when tutors used them to address sentence-level concerns. Similarly, the writers perceived Reader Response as a more effective strategy when used to support tutors' suggestions to correct global rather than sentence-level issues.

Written Commentary. In addition to conducting one-to-one writing conferences, some lawstudent writing tutors are required to read and comment on writers' texts before their conferences. While writing effective comments and conducting successful one-to-one conferences share many of the same tutoring strategies, several "hallmarks of the comment genre" (Fitzgerald \& Ianetta, 2016, p. 158), or "best practices" in providing written commentary, have evolved from the large body of scholarship on responding to students' writing. These "best practices" include: (a) writing both marginal and end comments, and explaining their relationship; (b) starting end comments with praise; (c) focusing on global issues; (d) selecting one or two patterns of sentence-level errors; (e) drawing on specific examples from writers' own texts; and (f) suggesting a limited number of substantive changes.

In order to capture additional commenting practices unique to tutoring in the law-school context, I relied on a noteworthy study conducted by Enquist (1996). In her study, Enquist explored what law students consider effective "critiquing" of their writing. From her analysis of the study data, Enquist found that:

- $\quad$ end comments are essential;

- students want in-depth explanations, examples, or both;

- $\quad$ students need positive feedback;

- too many comments can overwhelm some students;

- the most effective comments identify a problem and suggest a solution, and may offer a rationale for the solution; and

- some students react negatively to comments phrased as questions.

Based on Enquist's study, I added two additional best practices for providing written commentary to the tutor training criteria: (1) identify a problem and suggest a solution, and offer a rationale for the solution; and (2) limit the number of comments and questions.

Disciplinary Expertise. The writing centre literature suggests that a tutor's specialized knowledge and familiarity with discipline-specific discourse conventions may contribute to writing conference success (e.g., Dinitz \& Harrington, 2014). While certain scholars caution that tutors with 
Volume 27, 2017

http://journals.sfu.ca/cjsdw

disciplinary expertise are more likely to appropriate writers' work and dominate their writing conferences (e.g., Hubbuch, 1988), others believe that a tutor's knowledge of writing in the discipline is fundamental to writing conference success (e.g., Dinitz \& Harrington, 2014; McAndrew \& Reigstad, 2001). McAndrew and Reigstad (2001), for example, believe that tutors' disciplinary knowledge can be particularly helpful because it enables tutors to read writers' work like their target audience "experts in the discipline" (p. 73). And Dinitz and Harrington found a "strong connection" (2014, p. 73) between a tutor's knowledge of writing in the discipline and overall conference success.

Because very few writing centre scholars have explored the role of disciplinary knowledge in writing conference success, I relied heavily on Dinitz and Harrington's (2014) study in developing the disciplinary knowledge element of the tutor training criteria and in including most of the directive tutoring strategies.

In their small-scale study examining the role of tutors' disciplinary expertise in conferences with history and political science students, Dinitz and Harrington - and three faculty members from each discipline - analyzed a sample of students' papers and conference transcripts. Faculty members' analyses focused on the effectiveness of the conferences and the role played by the tutors' knowledge of writing in the discipline.

From their overall evaluation of the study data, Dinitz and Harrington found that tutors' disciplinary expertise played a pivotal role in writing conference success. More particularly, Dinitz and Harrington discovered that tutors' disciplinary expertise led to more productive and focused conferences because it enabled tutors to consistently:

- negotiate and follow an agenda focused on global writing concerns rather than sentencelevel concerns;

- assess writers' work accurately;

- ask questions that help writers identify and address key issues;

- evaluate and challenge writers' ideas, perspectives, and opinions;

- provide important knowledge and guidance about disciplinary writing conventions necessary for writers to move forward with their writing;

- push writers to higher levels of thinking and writing ability; and

- use directive tutoring strategies to facilitate and enhance collaboration.

Dinitz and Harrington also identified "two signature moves" (p. 89) that tutors with disciplinary expertise made in successful conferences: first praising writers' work, then pushing writers to do more. 
Volume 27, 2017

http://journals.sfu.ca/cjsdw

Conferences with tutors lacking disciplinary expertise were less successful for the opposite reasons. For example, tutors without disciplinary expertise were often not directive enough, asked unhelpful questions, failed to recognize writers' incorrect knowledge about writing in the discipline, "deferred too quickly to students' inaccurate assessments and opinions" (p. 93), did not identify and focus on global writing concerns, and "too readily agreed to go through a paper sentence by sentence" (p. 93).

What Dinitz and Harrington found particularly "surprising and alarming" (p. 83) was that tutors lacking disciplinary expertise failed to draw on their past experience, training, and preparation. In attempting to explain this finding, Dinitz and Harrington suggest that tutors' lack of disciplinary expertise prevented them "from accessing the full range of tutoring strategies they had at their disposal" (p. 93), while, in contrast, disciplinary expertise enabled tutors "to implement the core lessons from their tutor training" (p. 92)

Arguably, the fundamental factor contributing to writing conference success is a well-trained tutor (e.g., Goggin, 1988). Based on Dinitz and Harrington's study, training for tutors providing discipline-specific writing support to their peers should help tutors develop specialized knowledge about, and familiarity with, discipline-specific discourse conventions. Such training should also teach tutors how to use the directive strategies identified in Dinitz and Harrington's study to facilitate and enhance collaboration.

\section{Common Approaches to, and Features of, Effective Tutor Training}

While writing centre literature offers a wide array of approaches for training peer writing tutors, most writing centre scholars agree that tutor training cannot fully prepare tutors for every challenge they may face in their practices. There is also widespread agreement in writing centre scholarship that training should combine theory and practice, and be: (a) ongoing (e.g., Gilwicz \& Thonus, 2003); (b) based on more than a training manual (e.g., Bickford, 2006); and (c) "tailor-made" (Glassman, 1982, p. 129) to each particular writing centre.

The overarching goal of tutor training, according to many writing centre scholars, should be the development of a "well-rounded' tutor capable of addressing "writing issues while establishing rapport with the writer" (Bickford, 2006, p. 151). In Bickford's view (2006), the best way to achieve that goal is through a "magic combination" (p. 170) of making tutors aware of their writing processes, introducing them to current research and practices in writing instruction, and offering them practical suggestions and experience in tutoring. 
Volume 27, 2017

http://journals.sfu.ca/cjsdw

Common Training Formats. The two most common tutor-training formats are a structured credit-bearing classroom course and a less formal series of seminars or workshops (Bickford, 2006). Although training and tutoring may start simultaneously, training typically occurs at two specific times - before tutoring begins and while tutoring is in progress (Arfken, 1982). One of the most highly regarded and influential writing centres in the United States - the Purdue Writing Lab - trains its "consultants" through a combination of a credit-based course on peer tutoring, a mentoring program, regular staff meetings, and professional development activities (Rodriguez, 2012, p. 114).

Practical Training and Reflective Activities. Many writing centre scholars suggest that tutortraining programs should encourage tutors to study the tutoring process and practice tutoring techniques (e.g., Garrett, 1984). Practical exercises-like role-playing, practice sessions, and simulations-allow tutors to explore the tutoring process and develop a repertoire of tutoring strategies to help them conduct successful writing conferences. Through these exercises and followup group discussions, tutors build their interpersonal communication skills, begin to understand how writing conferences differ from classroom instruction (Harris, 1986), and learn to work within time constraints (Harris, 1986). Engaging in practical exercises also helps tutors recognize the benefits of both focusing conferences on one or two major issues (e.g., Olson, 1984) and providing writers with a reader's response to their texts (Harris, 1986). Perhaps most importantly, practical training exercises guide tutors in finding the right balance between writer-centred and tutor-dominant tutoring - the hallmark of effective tutor training, according to several modern writing centre theorists.

Another key component of tutor training identified in the writing centre literature is teaching tutors how to "proactively reflect" (Fitzgerald \& Ianetta, 2016, p. 52) on what they are learning and doing. Some of the more common reflective activities included in tutor-training programs are: (a) writing about and discussing personal impressions of course readings and activities, and participants' tutoring experiences; (b) observing conferences and completing post-observation reports; (c) performing self-evaluation; and (d) preparing reports after conducting writing conferences. According to Fitzgerald \& Ianetta (2016), reflective activities are "essential" (p. 52) to active learning and tutoring because they help tutors better understand, develop, and hone their practice.

Discipline-Specific Tutor Training. The final area of the writing centre literature I relied on in developing the tutor training criteria relates to discipline-specific tutor training.

While very little has been written about effective discipline-specific tutor training per se, the 
Volume 27, 2017

http://journals.sfu.ca/cjsdw

training literature related to tutoring across the curriculum offers some useful ideas. For example, Scanlon (1986) suggests that faculty conduct discipline-specific workshops for tutors lacking disciplinary expertise. Other ideas include teaching generalist tutors how to: (a) transfer their general tutoring knowledge to discipline-specific contexts; (b) resist abdicating responsibility to writers too quickly; (c) avoid feeling intimidated when writers present views that conflict with their own; and (d) apply "a repertoire of possible polite and sophisticated push-back techniques used by tutors with disciplinary expertise" (Dinitz \& Harrington, 2014, p. 95). To ensure that tutors with disciplinary expertise do not lose sight of their tutoring role, or forget their general tutoring knowledge, Fitzgerald \& Ianetta (2016) suggest that specialist tutors conferencing with writers in their discipline learn to emphasize active listening and guided questioning techniques, and adopt a "provisional, less-than-absolutely-certain stance" (p. 152).

In one of the few North American law-school writing centres, tutor training is structured around a half-day orientation session and a week-to-week companion course (Murray, 2011). Before the orientation session, tutors read "The Listening Eye: Reflections on the Writing Conference" (Murray, 1979) and "The Idea of a Writing Center" (North, 1984). The orientation session itself includes a lecture on preparing for and conducting conferences, as well as two simulation exercises. The session also introduces tutors to the law school's first-year legal research and writing program and the writing centre's mission. The companion course focuses on refining tutors' knowledge of the substantive law relevant to the major required first-year assignments and training tutors to work with the different types of writers with whom they will be conferencing.

\section{Part II. Training Writing Tutors at the University of Ottawa's Law School}

The University of Ottawa, located in the nation's capital, houses the largest law school in Canada. Through its separate common law and civil law sections, the law school offers professional training in Canada's two legal systems. The civil law program is taught entirely in French and trains lawyers to practice in Quebec. The common law program trains lawyers to practice in the other provinces, and is taught in both French and English.

The University of Ottawa's law school stands apart from the rest of Canada's law schools in offering a variety of legal writing options throughout its entire three-year curriculum. An innovative initiative called the Legal Writing Academy (LWA) provides writing instruction to students in the English common law program through upper-year credit courses; writing units integrated into traditional first-, second-, and third-year courses; first-year writing workshops; and faculty-wide 
Volume 27, 2017

http://journals.sfu.ca/cjsdw

writing workshops and peer writing conferences. I teach upper-level legal writing in the English common law program and am one of the LWA program co-directors.

In the spring of 2012, two of my LWA colleagues and I created a program to train a cohort of upperyear law students to conduct peer writing conferences and provide their fellow students with frequent written feedback on their writing. The training program evolved from my colleagues' and my collective experiences teaching law and legal writing, my academic background in writing studies, and my work as a university writing tutor. While the content and structure of the program have changed over the years, the learning objectives have remained the same. In the section that follows, I describe the program offered during the 2016/17 academic year, which incorporates many of the tutor training criteria (refer to appendix).

\section{The Legal Writing Academy's Peer Writing Tutor Training Program}

For ease of reference, my discussion of the LWA's peer writing tutor training program (the LWA tutor training program) is organized around the six topic headings used in the tutor training criteria: tutor selection process, training format, understanding of the writing process and writing development, disciplinary knowledge, understanding of the tutoring process and tutoring strategies, and ability to provide written commentary on student texts.

Tutor Selection Process. During each of the Fall and January Terms, 12 tutors were selected from a pool of current law student applicants on the basis of their writing and interpersonal skills. As part of the application process, students were required to submit a cover letter, two references, their law school transcripts, their curriculum vitae, and a brief sample of their legal writing. Many of the shortlisted applicants were interviewed.

Training Format. The LWA training program starts with a 39-hour experiential and active learning classroom course designed to train law students to provide writing support to their peers (the course), and continues on an ad-hoc basis while tutoring is in progress. The course's specific learning objectives include: refining tutors' writing skills; polishing tutors' self-editing techniques; educating tutors about their writing process; sharpening tutors' interpersonal and leadership skills; and teaching tutors how to talk about writing, identify their peers' writing needs, and respond to their peers' writing in a balanced way. To meet these learning objectives, the course is divided into three general topic areas related to the learning and teaching of legal writing: effective writing and editing; law-specific discourse conventions; and peer feedback principles and practices.

Course content is delivered through: assigned readings; lectures by the course instructors and a 
Volume 27, 2017

http://journals.sfu.ca/cjsdw

practicing lawyer; graded assignments; writing and editing exercises; class discussions; peer review exercises; a conference demonstration; two classroom practice conferences; an analysis of a live conference; and a 20-minute conference with the main course instructor. Assigned readings include a customized tutoring handbook (the tutoring handbook) and tip sheets created by LWA instructors, a legal writing website, sample legal documents, and supplemental published articles.

Understanding of the Writing Process and Writing Development. During the course, lectures, assigned readings, and group discussions, as well as developing and using personal revising checklists, provided tutors with the means to acquire knowledge about the writing process. The tutors were also given the opportunity to develop their own writing abilities through a writing selfassessment assignment, targeted writing exercises, peer reviews, instructor feedback on their graded assignments, and a writing conference with the main course instructor.

Disciplinary Knowledge. The course offered tutors several ways to expand their knowledge about, and familiarity with, law-specific discourse conventions. For example, many of the course components focused on teaching the tutors how to write three specific legal documents: a legal memorandum, a client advice letter, and a demand letter. At the end of the course, tutors completed an assignment geared toward developing their knowledge about, and familiarity with, general legal writing principles - an explanatory and descriptive list of their "top ten" legal writing lessons learned during the course.

Understanding of the Tutoring Process and Tutoring Strategies. While the course did not introduce tutors to current research in writing instruction, it did expose tutors to different writing instruction practices. For example, the tutors were introduced to experiential learning activities, the peer review process, and one-on-one writing conferencing with both their peers and their instructors. Concerning the tutors' understanding of the theoretical foundations of tutoring writing, the tutoring handbook contains guidelines for conducting writing conferences that are drawn from writing centre scholarship, copies of theory-related journal articles, and a bibliography of supplementary theoretical readings. Two brief class lectures also focused on writing tutoring theory.

Regarding tutoring practice and reflective activities, tutors analyzed a videotaped writing conference demonstration, participated in two practice conferences with their classmates, and observed a live conference conducted by an experienced tutor. Following the conference observation, tutors completed an assignment that asked them to do four specific things:

- summarize the conference they observed by identifying the main topics discussed and tutoring strategies used to address each topic; 
Volume 27, 2017

http://journals.sfu.ca/cjsdw

- analyze the experienced tutor's use of the strategies identified by answering several guiding questions;

- explain how the conferencing process they observed reflects elements of the process described in the tutoring handbook and discussed in class; and

- discuss their observation experience with me.

Frequent class discussions also provided tutors with regular opportunities to reflect on course content, which included tutoring experiences from time to time. The tutoring handbook also recommends that tutors engage in one or more of the following self-assessment activities:

- keep a conferencing journal to jot down personal impressions and observations of conferencing experiences as they arise;

- complete a personal checklist of conferencing skills from time to time; and

- complete a conferencing typology every now and again to help tutors become more aware of their personal conferencing styles as they evolve.

When graduates of the course begin conducting conferences on their own, they must complete a post-conference report within two days of each conference. In their post-conference reports, tutors describe all writing topics discussed, advice given, challenges faced, and tutoring strategies used.

Concerning tutoring strategies, tutors were introduced to different tutoring strategies by analyzing the videotaped conference demonstration, participating in the classroom practice conferences, and observing and reflecting on the live conference.

Ability to Provide Written Commentary on Student Texts. One class during the course was devoted to introducing tutors to best practices for providing written commentary. The best practices are also included in the tutoring handbook.

\section{Conclusion}

After five years of experimenting with different curricula and pedagogical approaches, the LWA training program now incorporates many of the tutor training criteria. Each term, 12 upper-year law students are chosen to participate in the program on the basis of their writing and interpersonal skills. Training is ongoing, customized, and based on more than a training manual. The program provides tutors with the means to acquire knowledge about the writing process, develop their writing abilities, and expand their knowledge about, and familiarity with, law-specific discourse conventions. The program introduces tutors to writing tutoring theory, a variety of writing instruction practices, different tutoring strategies, and best practices for providing written 
Volume 27, 2017

http://journals.sfu.ca/cjsdw

commentary. The program also provides tutors with opportunities to practice tutoring, observe and analyze conferences, and engage in reflective activities.

The program offered in 2016/17 looks much different than the one offered in 2012/13. In the early years, the program focused on strengthening tutors' general writing and editing abilities, and expanding their knowledge about, and familiarity with, law-specific discourse conventions. Tutors learned about writing tutoring theory in the course by reading and discussing two brief journal articles; they were introduced to tutoring practices by observing one 15-minute mock writing conference and conducting one 30-minute practice writing conference.

Based on my LWA colleagues' and my observations of the tutors' conferences in the first year, the tutors' feedback, and our review of the tutors' post-conference reports, we made several changes to the program over the years. Some of the more recent changes include: creating the tutoring handbook; introducing more theory into the course; expanding the reflective activities; and providing tutors with more opportunities to practice tutoring, as well as observe and analyze conferences. New tutors tell us that these latter activities are particularly helpful in bridging the gap between theory and practice, and in building their confidence. One of the main changes we are planning for the Fall 2017 Term is an individual "refresher" meeting with each of the returning tutors before they conduct their first conference in the new academic year.

Our next challenge will be discovering ways to ensure that all tutors consistently transfer the teachings from their training to their practices.

I hope that writing centre directors and others tasked with developing training for peer writing tutors will draw on the tutor training criteria and the LWA training program in designing their own unique approaches to training discipline-specific writing tutors. Using the tutor training criteria in this way will help writing centres meet three Best Instructional Practices for Writing Centres: (1) peer tutors need to be educated and mentored, (2) writing support is best attended to in disciplinary contexts, and (3) writing professionals use and apply research from writing studies.

\section{References}

Arfken, D. (1982). A peer-tutor staff: Four crucial aspects. In M. Harris (Ed.), Tutoring writing: A sourcebook for writing labs (pp. 111-122). Glenview, IL: Scott, Foresman, and Company.

Bannister-Wills, L. (1984). Developing a peer tutor program. In G.A Olson (Ed.), Writing centers: Theory and administration (pp. 132-143). Urbana, IL: National Council of Teachers of English. 
Volume 27, 2017

http://journals.sfu.ca/cjsdw

Bickford, C. (2006). Examining writing center training texts: Towards a tutor training pedagogy (Unpublished doctoral dissertation). Indiana University, Pennsylvania.

Bizzell, P. (1982). Cognition, convention, and certainty: What we need to know about writing. In V. Villanueva (Ed.), Cross-talk in comp theory: A reader (2nd ed., pp. 387-411). Urbana, IL: National Council of Teachers of English.

Blau, S., \& Hall, J. (2002). Guilt-free tutoring: Rethinking how we tutor non-native-English speaking students. The Writing Center Journal, 23(1), 23-44.

Blau, S., Hall, J., \& Strauss, T. (1998). Exploring the tutor/client conversation: A linguistic analysis. The Writing Center Journal, 19(1), 19-49.

Brooks, J. (1991). Minimalist tutoring: Making the student do all the work. Writing Lab Newsletter, 15(6), 1-4.

Brown, K. (2008). Breaking into the tutor's toolbox: An investigation into strategies used in writing center tutorials (Unpublished doctoral dissertation). University of Louisville, Kentucky.

Bruffee, K. (1984). Collaborative learning and the "conversation of mankind". College English, 46, 635-652.

Dinitz, S. \& Harrington, S. (2014). The role of disciplinary expertise in shaping writing tutorials. The Writing Center Journal, 33(2), 73-98.

Ede, L. (1989). Writing as a social process: A theoretical foundation for writing centers? The Writing Center Journal, 9, 3-13.

Enquist, A. (1996). Critiquing law students' writing: What the students say is effective. Journal of the Legal Writing Institute, 2, 145-209.

Fitzgerald, L., \& Ianetta, M. (2016). The Oxford guide for writing tutors: practice and research. New York, NY: Oxford University Press.

Flower, L., \& Hayes, J. (1981). A cognitive process theory of writing. College Composition and Communication, 32, 365-387.

Freedman, A. (1984). The Carleton university writing tutorial service. Carleton Papers in Applied Language Studies, 1, 77-100.

Freedman, A., \& Medway, P. (1994). Introduction: New views of genre and their implications for education. In A. Freedman \& P. Medway (Eds.), Learning and teaching genre (pp. 1-22).

Portsmouth, NH: Boynton/Cook. 
Volume 27, 2017

http://journals.sfu.ca/cjsdw

Garrett, M. P. (1984). Toward a delicate balance: The importance of role playing and peer criticism in peer-tutor training. In M. Harris (Ed.), Tutoring writing: A sourcebook for writing labs (pp. 94100). Glenview, IL: Scott, Foresman, and Company.

Gillespie, P., \& Lerner, N. (2008). The Longman guide to peer tutoring (2nd ed.). New York, NY: Pearson Education, Inc.

Gilwicz, M., \& Thonus, T. (2003). Close vertical transcription in writing center training and research. The Writing Center Journal, 24(1), 25-49.

Glassman, S. (1982). Tutor training on a shoestring. In M. Harris (Ed.), Tutoring writing: A sourcebook for writing labs (pp. 123-129). Glenview, IL: Scott, Foresman, and Company.

Goggin, M. D. (1988). Training tutors to work with student writers. The Writing Lab Newsletter, 12, 8-11.

Graves, R. (2016). Statement on writing centres and staffing. Canadian Journal for Studies in Discourse and Writing/Rédactologie, 26, 5-10.

Harris, M. (1986). Teaching one-to-one: The writing conference. Urbana, IL: National Council of Teachers of English.

Harris, M. (1995). Talking in the middle: Why writers need writing tutors. College English, 57, 27-42.

Henning, T. B. (2001 March 14-17). Theoretical models of tutor talk: How practical are they? Paper presented at the Annual Meeting of the Conference on College Composition and Communication. Denver, C0. (pp. 1-12).

Hobson, E. H. (1992). Maintaining our balance: Walking the tightrope of competing epistemologies, The Writing Center Journal, 13(1), 65-75.

Hubbuch, S.M. (1988). A tutor needs to to know the subject matter to help a student with a paper: Agree disagree not sure. The Writing Center Journal, 8, 23-30.

McAndrew, D.A., \& Reigstad, T.J. (2001). Tutoring writing: A practical guide for conferences. Portsmouth, NH: Boynton/Cook Publishers, Inc.

Murray, D. M. (1979). The listening eye: Reflections on the writing conference. College English, 41(1), 13-18.

Murray, K. E. (2011). Peer tutoring and the law school writing center: Theory and practice. The Journal of the Legal Writing Institute, 17, 162-196.

North, S. M. (1982). Training tutors to talk about writing. College Composition and Communication, $33(4), 434-441$.

North, S. M. (1984). The idea of a writing center. College English, 46, 433-446. 
Volume 27, 2017

http://journals.sfu.ca/cjsdw

Olson, G.A. (1984). Establishing and maintaining a writing center in a two-year college. In G.A Olson (Ed.), Writing centers: Theory and administration (pp. 87-100). Urbana, IL: National Council of Teachers of English.

Rodriguez, S. (2012). Letting students teach each other: Using peer conferences in upper-level legal writing. Florida Coastal Law Review, 13, 101-148.

Scanlon, L. C. (1986). Recruiting and training tutors for cross-disciplinary writing programs. The Writing Center Journal, 37-41.

Sloan, P. (2007). Contextualizing writing centres: Theory vs. practice (Unpublished Master's thesis). Carleton University, Ottawa.

Stonerock, K. H. (2005). From training to practice: The writing center as a setting for learning to tutor (Unpublished doctoral dissertation). The Ohio State University, Ohio.

Swales, J. M. (1990) Genre analysis: English in academic and research settings. New York: NY, Cambridge University Press.

University of Toronto. (2017). Writing Centres. Retrieved from http://writing.utoronto.ca/writingcentres/

Young, R. (1978). Paradigms and problems: Needed research in rhetorical invention. In C. Cooper \& L. Odell (Eds.), Research in composing: Points of departure (pp. 29-47). Urbana, IL: National Council of Teachers of English. 
Volume 27, 2017

http://journals.sfu.ca/cjsdw

\section{Appendix}

The table that follows presents the tutor training criteria I developed by synthesizing the essential ideas from the literature related to writing centre pedagogy, the writing process, and effective training for peer writing tutors discussed in Part I. The table is organized under six topic headings: (1) Tutor Selection Process; (2) Training Format; (3) Understanding of the Writing Process and Writing Development; (4) Disciplinary Knowledge; (5) Understanding of the Tutoring Process and Tutoring Strategies; and (6) Ability to Provide Written Commentary on Student Texts. The table lists the tutor training criteria and indicates the related themes from the supporting literature as explained in Part I.

\begin{tabular}{|c|c|}
\hline $\begin{array}{l}\text { Criteria for Effective Training for Peer } \\
\text { Writing Tutors }\end{array}$ & $\begin{array}{l}\text { Themes in the Supporting Areas of } \\
\text { the Literature }\end{array}$ \\
\hline $\begin{array}{l}\text { Tutor Selection Process } \\
\text { Tutors are chosen from a pool of current student } \\
\text { applicants based on certain personal attributes, } \\
\text { such as: } \\
\text { - good listening skills; } \\
\text { - patience; } \\
\text { - } \quad \text { adaptability; } \\
\text { - } \quad \text { adeptness at establishing and maintaining } \\
\text { - receptivity to new learning; and } \\
\text { - true concern for helping writers. }\end{array}$ & $\Rightarrow$ Writing Tutors' Personal Attributes \\
\hline $\begin{array}{l}\text { Training Format } \\
\text { Tutors receive training that is: } \\
\text { - } \quad \text { customized to the particular writing centre; } \\
\text { - balanced between theory and practice; } \\
\text { - based on more than a training manual; and }\end{array}$ & $\begin{aligned} \Rightarrow & \text { Common Training Approaches } \\
& \text { Common Training Formats } \\
& \text { Discipline-Specific Tutor Training }\end{aligned}$ \\
\hline
\end{tabular}


Volume 27, 2017

http://journals.sfu.ca/cjsdw

\begin{tabular}{|c|c|}
\hline ongoing. & \\
\hline $\begin{array}{l}\text { Understanding of the Writing Process and } \\
\text { Writing Development } \\
\text { 1. Tutors acquire and are able to apply knowledge } \\
\text { about the writing process. For example, tutors: } \\
\text { - understand writing as a process of } \\
\text { investigation and discovery; } \\
\text { - become aware of their own writing processes; } \\
\text { and } \\
\text { gain insight into other writers' writing } \\
\text { processes. } \\
\text { continuously (and self-reflexively) developing } \\
\text { their own writing abilities. }\end{array}$ & $\begin{array}{c}\Rightarrow \text { Common Training Approaches } \\
\text { Common Training Formats }\end{array}$ \\
\hline $\begin{array}{l}\text { Disciplinary Knowledge } \\
\text { Tutors develop specialized knowledge about, and } \\
\text { familiarity with, discipline-specific discourse } \\
\text { conventions. }\end{array}$ & $\Rightarrow$ Disciplinary Expertise \\
\hline $\begin{array}{l}\text { Understanding of the Tutoring Process and } \\
\text { Tutoring Strategies } \\
\text { 1. 1Tutors are introduced to current research and } \\
\text { practices in writing instruction. }\end{array}$ & $\begin{aligned} \Rightarrow & \text { Common Training Approaches } \\
& \text { Common Training Formats }\end{aligned}$ \\
\hline $\begin{array}{l}1.2 \text { Tutors understand the theoretical foundations } \\
\text { of tutoring writing. } \\
1.3 \text { Tutors have ample opportunities to practice } \\
\text { tutoring. }\end{array}$ & $\begin{array}{l}\Rightarrow \text { The Three Main Theories } \\
\Rightarrow \text { Common Training Approaches } \\
\text { Common Training Formats } \\
\text { Practical Training and Reflection }\end{array}$ \\
\hline
\end{tabular}


Volume 27, 2017

http://journals.sfu.ca/cjsdw

\subsection{Tutors regularly engage in reflective activities,} such as:

- $\quad$ reflecting about course content and tutoring experiences;

- observing and analyzing conferences; and

- performing self-evaluation.

2. Tutors develop a repertoire of effective directive and nondirective strategies, and continuously adapt these strategies in a balanced and flexible way, to address their peers' writing concerns. For example, tutors demonstrate the ability to use the following strategies:

- build rapport;

- actively listen;

- ask open-ended questions;

- give specific and authentic praise;

- talk about the writing process;

- teach self-editing techniques;
$\Rightarrow$ Common Training Approaches

Practical Training and Reflection

$\Rightarrow$ Three Key Characteristics of Successful Writing Conferences

$\Rightarrow$ Three Key Characteristics of Successful Writing Conferences

$\Rightarrow$ Tutors' Use of Specific Tutoring Strategies Discipline-Specific Tutor Training

$\Rightarrow$ Tutors' Use of Specific Tutoring Strategies Discipline-Specific Tutor Training

$\Rightarrow$ Tutors' Use of Specific Tutoring Strategies

$\Rightarrow$ Tutors' Use of Specific Tutoring Strategies

$\Rightarrow$ Tutors' Use of Specific Tutoring Strategies 
Volume 27, 2017

http://journals.sfu.ca/cjsdw

- suggest revisions for writers to make on their own;

- offer a reader's response to a writer's work;

- negotiate conference agendas that meet writers' expectations;

- $\quad$ structure conferences around global writing concerns rather than sentence-level concerns;

- focus on patterns of error when addressing sentence-level concerns;

- $\quad$ address a limited number of issues;

- evaluate and challenge writers' ideas, perspectives, and opinions;

- provide important information and guidance about disciplinary writing conventions necessary for writers to move forward with their writing;

- $\quad$ push writers to higher levels of thinking and writing ability; and
$\Rightarrow$ Tutors' Use of Specific Tutoring Strategies

$\Rightarrow$ Tutors' Use of Specific Tutoring Strategies

$\Rightarrow$ Three Key Characteristics of Successful Writing Conferences

Tutors' Use of Specific Tutoring Strategies Disciplinary Expertise

$\Rightarrow$ Tutors' Use of Specific Tutoring Strategies Disciplinary Expertise

$\Rightarrow$ Tutors' Use of Specific Tutoring Strategies

$\Rightarrow$ Tutors' Use of Specific Tutoring Strategies

$\Rightarrow$ Disciplinary Expertise

$\Rightarrow$ Three Key Characteristics of Successful Writing Conferences

Disciplinary Expertise

$\Rightarrow$ Disciplinary Expertise 
Volume 27, 2017

http://journals.sfu.ca/cjsdw
- praise writers' work, then push them to do more.

When working with multilingual writers, tutors consider using one or more of the following strategies:

- offer to read various sections of the writer's document aloud;

- be directive and to the point when explaining sentence-level concerns related to mechanics, idioms, or grammar;

- go through part of the writer's document line by line and discuss as many problems with clarity and sentence construction as possible; and

- interweave discussions of both global and sentence-level concerns, focusing on sentencelevel errors that affect the document's overall clarity and meaning.

\section{Ability to Provide Written Commentary on}

\section{Student Texts}

Tutors demonstrate the ability to follow best practices for providing written commentary, such as:

- $\quad$ starting with the positive;

- drawing on specific examples from writers' own texts;

- identifying a problem and suggesting a solution, and offering a rationale for the solution;
$\Rightarrow$ Disciplinary Expertise

$\Rightarrow$ Tutors' Use of Specific Tutoring Strategies
$\Rightarrow$ Written Commentary 
Volume 27, 2017

http://journals.sfu.ca/cjsdw

- limiting the number of comments, substantive changes, and questions;

- prioritizing global writing concerns over sentence-level concerns;

- pointing out one or two patterns of sentencelevel errors; and

- providing marginal and end comments, and explaining the relationship between the two types of comments. 